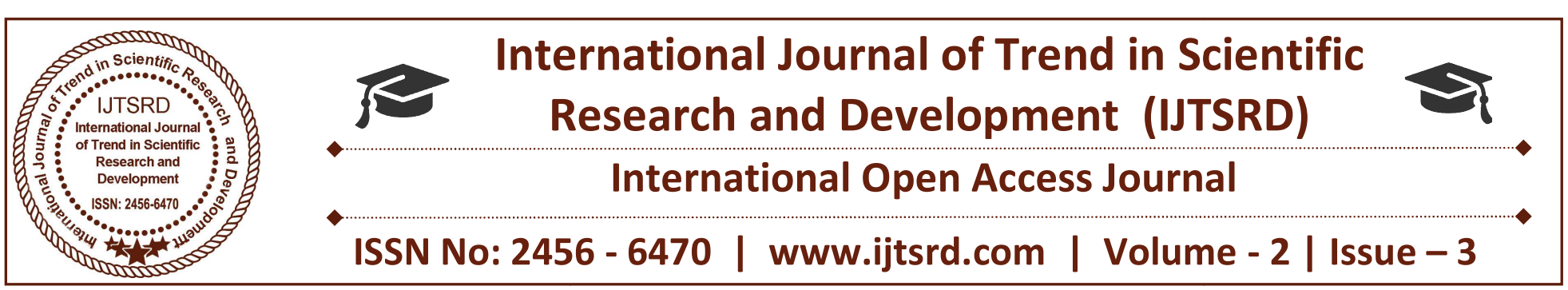

\title{
Present Scenario and Technical Review of Smart Grid in India
}

\author{
Rahul Yadav ${ }^{1}$, Mr. Kushaldeep Sharma ${ }^{2}$, Dr. Deepika Chauhan ${ }^{3}$ \\ ${ }^{1}$ Student, ${ }^{2}$ Assistant Professor, ${ }^{3}$ Associate Professor \\ Department of Electrical Engineering, Poornima College of Engineering, Jaipur, Rajasthan, India
}

\section{ABSTRACT}

Smart grid is in its developing stage in India. National Smart Grid Mission (NSGM) was propelled by Ministry of Power, that designs and screens approaches and programs for improvement and sending of keen matrix in India. Aggregate of 14 pilot tasks and 1 brilliant city project are declared. The objective set by country is to accomplish sustainable power source age of $175 \mathrm{GW}$ by 2022. This exhibits the power framework organizers with a test to guarantee access for prosumers to present day vitality which is ecologically, institutionally and financially manageable. The draining fuel assets, breaking down ecological conditions and consistently expanding power requests make up and coming the modernization of the power transmission and conveyance systems. Further, savvy lattice approaches embraced worldwide are portrayed and a short survey of different continuous ventures in India and standards set by Indian government for the actualizing organization of cutting edge metering foundation (AMI) is introduced.

The thought behind 'Savvy Grid Vision for India' is tochange the Indian power division into a safe, versatile, feasible, and carefully empowered biological community that gives dependable and quality vitality to all with dynamic interest of partners. The principle goal of this specialized paper is to underline the present situation of those chose Smart Grid pilots in India, including proposed best in class Technology Integration.

Keywords: smart grid; AMI; distributed energy generation \& $R$ - $A P D R P$

\section{INTRODUCTION}

Power lattices are required for interconnecting the power age plants that are situated at various areas, with the purchasers situated in the diverse urban areas. By and by there is one-way information correspondence in the power framework Smart lattice can alter the way show power matrices are checked and controlled in Indian matrix framework, the standard voltages on the appropriation side are $66 \mathrm{kV}$, $33 \mathrm{kV}, 22 \mathrm{kV}, 11 \mathrm{kV}$ and $400 / 230$ volts, notwithstanding $6.6 \mathrm{kV}, 3.3 \mathrm{kV}$ and $2.2 \mathrm{kV}$ as the dispersion exudes from the point where transmission leaves off at the $66 / 33 \mathrm{kV}$ levels. The Govt. of India made substantial interests in the circulation division through different arrangements and controls like the Rajiv Gandhi GrameenVidyutikaranYojna (RGGVY) what's more, Accelerated Power Development and Reforms Program (APDRP) to give access of power to all and cut down the AT\&C misfortunes the nation over The unidirectional idea of correspondence and incorporated age makes the conventional matrices less effective, accordingly reengineering of current network is required such that they can take care of expanding demand, are less inclined to deficiencies and influence misfortune, lessen power burglaries and air contamination, broadens life of hardware etc. They are self-mending, have proficient OMS, decrease ozone depleting substance discharge and spotlight on enhancing the PQ.

\section{SMART GRID}

Keen network is ways to deal with modernize the customary power matrix by joining advanced correspondence, data innovation frameworks, and mechanized control and observing for ongoing or almost constant load request coordinating. Shrewd framework supports cooperation of clients, can 
incorporate a wide range of energy producing frameworks with arrangements for capacity, and can guarantee great power quality. Savvy network can better incorporate the irregular sustainable power source age. It can likewise diminish cost of pinnacle control by expanded perceivability, consistency, and even control of age and request.

\section{A. Compression between Traditional Electric Grid and Smart Grid}

Conventional framework is portrayed by motorized activity with one-way correspondence. It has spiral system with less information, modest number of sensors, and is generally observed, controlled, and recouped physically. Then again, savvy network is described by digitized activity. It has two-way correspondence and appropriated control age sources associated with it. The system has substantial number of sensors introduced for different parameter accumulations. Savvy matrix gives programmed checking, recuperating, and control since huge measure of information gathered utilizing sensors is engaged with basic leadership.

\section{B. Benefits of smart grid}

Shrewd framework encourages the purchasers in overseeing power all the more effectively by executing useful show gadgets and continuous charging data. In this way buyers can change their power uses amid top request hours and take the advantages of minimal effort control from inexhaustible age sources. The shrewd matrix is better intended to oversee discontinuous wellsprings of power. It additionally gives more control over low carbon regular age and hence helping in the utilization of hardware of framework foundation all the more proficiently. This at last limits the cost associated with vitality age and utilization.

\section{PRESENT STATUS}

In the previous years, analysts have proposed strategies to decide the ideal area and measuring of DGs in dispersion organizes by altering customary calculations or by utilizing cross breed calculations. Studies show that in a power framework, distinctive principles have been built up to give stipulations or proposals to guarantee acceptable voltage profiles. Upkeep of voltage solidness relies upon the harmony between stack request and supply. One of the broadly embraced strategies for enhancing voltage profiles of conveyance frameworks is presenting circulated age (DG) in dispersion frameworks. The areas and size of
DGs would significantly affect the impact of voltage profile improvement. Change of voltage security edge utilizing DGs have been contemplated in, however the part of misfortune minimization isn't considered. In, the proposed strategy recognizes an ideal area for situation of DG considering misfortune diminishment affectability and voltage change affectability. Despite the fact that voltage profile change and line misfortune decrease can be accomplished by deliberately setting DG along the system, the truth of the matter is that, in the present dissemination framework, particularly in instances of DG area and estimating underneath a specific farthest point, the dispersion framework administrator (DSO) has for all intents and purposes no control or impact. Notwithstanding, with the appearance of brilliant network ideas like finish framework representation and bidirectional Correspondence and additionally applications like framework arranging, examination, diagnostics and expectation, these issues can be limited. In this specific situation, this paper examination the effect of DG joining in dispersion framework and draws out a calculation for adaptable DG coordination in savvy network situation.

\section{IMPACT ANALYSIS}

Load stream ponder is the fundamental instrument utilized for the examination, outline and arranging of energy/frameworks which guarantees that power supply from generators to buyers through power framework organize is steady, solid and monetary. Various regular calculations like Gauss Seidal, Newton Raphson and other decoupled strategies are utilized for transmission issues however the greater part of these techniques are not reasonable for dispersion framework described by high $\mathrm{R} / \mathrm{X}$ proportion and their topology is either outspread or pitifully fit with multiphase adjusted or uneven task and will get separated from the ideal arrangement. Load stream examination can be ingenious just if focalizes rapidly utilizing least memory. Subsequently various specific calculations exist for dispersion systems which incorporate Compensation technique, Implicit Gauss strategy, Modified Newton strategy and so on. In the present work, the heap stream ponders philosophy proposed by Ghosh and Das is utilized.

\section{SMART GRID POLICIES WORLDWIDE}

The International Energy Agency (IEA) has anticipated the overall power request to develop by 
$2.2 \%$ every year from 2012 to 2035 which can be met just by modernizing the current power lattice. European Union points towards executing savvy metering in $80 \%$ of families by the year 2020 . Their goal is characterized as 20:20:20 where they expect to diminish ozone depleting substances by $20 \%$, increment sustainable age by $20 \%$ and enhance vitality proficiency by $20 \%$ by the year 2020 . Its point is to build vitality autonomy proportion to $70 \%$, lessen $\mathrm{CO} 2$ outflow by half, raise zero emanation by control assets to around $70 \%$, acquire best offers for items also, frameworks identified with vitality and upgrade vitality productivity at largest amount on the planet by the year 2030 .

\section{SMART GRID IN INDIA}

India has added up to introduce limit of $314.64 \mathrm{GW}$ till Jan 31, 2017 [15], and per capita utilization of power is 2017 International Conference on Circuits Power and Computing Technologies [ICCPCT] 1075 $\mathrm{kWh}$. Add up to sustainable power source age is 50.02 GW till Dec 31, 2016 [16]. As indicated by Ministry of Power (MoP), transmission and dispersion misfortunes are among the most elevated in the world. So in India, savvy matrix can diminish these transmission and dispersion misfortunes and enhance influence framework strength. It will likewise help in clearing of energy produced through sustainable power sources. For quickening the advancement of brilliant network in India, clean had made early strides in 2010 by constituting the India Brilliant Grid Task Force and India Smart Grid Forum for encircling approaches and undertakings for the brilliant lattice improvement in India.

\begin{tabular}{|c|c|c|}
\hline Project Details & Technologies Adopted & Work Done \\
\hline $\begin{array}{l}\text { Chandigarh } \\
\text { Electricity } \\
\text { Department (CED), } \\
\text { Chandigarh } \\
\text { Managed by Rural } \\
\text { Electrification } \\
\text { Corporation Power } \\
\text { Distribution } \\
\text { Company Limited } \\
\text { (RECPCDL). } \\
\text { (29,433 consumers) }\end{array}$ & $\begin{array}{l}\text { AMI, DT } \\
\text { monitoring, substation automation, } \\
\text { rooftop solar photovoltaic } \\
\text { (PV) and end In Scientific } \\
\text { Information Technology } \\
\text { infrastructure functionalities. } \\
\quad \text { Development }\end{array}$ & $\begin{array}{l}\text { XCED was issued sanction letter in } \\
\text { April } 2016 \text {. } \\
\text { xSmart Grid cell and } \\
\text { SLPMU has been } \\
\text { formed }\end{array}$ \\
\hline $\begin{array}{l}\text { Maharashtra State } \\
\text { Electricity } \\
\text { Distribution } \\
\text { Corporation } \\
\text { Limited (MSEDCL), } \\
\text { Amravati, } \\
\text { Maharashtra } \\
\text { (1,48,000 consumers) }\end{array}$ & & $\begin{array}{l}\text { xMSEDCL was issued sanction letter } \\
\text { in April } 2016 \text {. } \\
\text { xTender document was floated on } \\
\text { December 22, 2016 and bid } \\
\text { submission was scheduled for } \\
\text { February 6, 2017. }\end{array}$ \\
\hline $\begin{array}{l}\text { MSEDCL, Congress Nagar, } \\
\text { Nagpur, } \\
\text { Maharashtra } \\
(1,25,000 \text { consumers })\end{array}$ & $\begin{array}{l}\text { AMI, SCADA, OMS and DR } \\
\text { functionalities }\end{array}$ & $\begin{array}{l}\text { xMSEDCL was issued sanction letter } \\
\text { in July } 2016 \text {. } \\
\text { xTender document was floated on } \\
\text { December 22, 2016 and bid } \\
\text { submission was scheduled for } \\
\text { February } 7,2017\end{array}$ \\
\hline 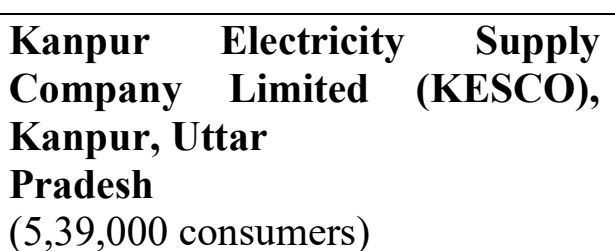 & $\begin{array}{l}\text { AMI, SCADA, OMS and DR } \\
\text { functionalities }\end{array}$ & $\begin{array}{l}\text { xSanction letter was issued to } \\
\text { KESCO by NSGM in November } \\
2016\end{array}$ \\
\hline
\end{tabular}




\section{Implementation of Smart Grid in India}

India has a reasonable vision of actualizing the brilliant lattice. India has set six goals to be accomplished till the finish of fourteenth five-year design in year 2027:

(i) Enable access and accessibility of value control for all: Till 2017, the objective is for charging all family units. By 2022, the objective is for giving 24-hour supply in urban territories what's more, least 12-hour to all purchasers and at last driving to quality power all the time till 2027.

(ii) Loss lessening: The objectives are to decrease Aggregate Specialized and Commercial Losses (AT\&C misfortunes) beneath $12 \%$ till 2022 and beneath $10 \%$ by 2027 . The high voltage transmission misfortunes are to be lessened underneath 3\% by 2027 .

(iii) Smart framework mechanization and Micro matrices: India intends to execute across the nation Advanced Metering Infrastructure (AMI) for all clients with 3-stage association and improvement of smaller scale frameworks in around 10,000 towns/ modern parks till 2022. The AMI for all clients and miniaturized scale networks in around 20,000 towns will be accomplished till 2027. (iv) Policies and Tariffs: India has executed net metering for rooftop top close planetary system till 2017. It is suggested that by 2022 the purchasers in metros and chose urban territories will have the decision of power provider and this decision will be accessible to all urban and country zones by 2027.

(v) Renewable vitality and Energy productivity: India designs to framework coordinate inexhaustible energy of $175 \mathrm{GW}$ by 2022 . Dynamic vitality productivity projects will be executed across the country till 2027.

(vi) Electric Vehicles and Energy Storage: The arrangement is to rollout huge number of vitality stockpiling frameworks and electric vehicle charging stations in every urban zone and couple of areas on thruways by 2022 . A definitive target is to have electric vehicle charging stations in all urban areas and along all state and national thruways by 2027.

\section{Present Status of Smart Grid Pilot Projects in India}

In this paper, the pilot projects that are being implemented in India are divided into four regions: a) Northern Region (NR); b) Southern Region (SR); c) Eastern Region (ER); and d) Western Region (WR).

\section{TABLE V: PILOT PROJECTS IN NORTHERN REGION OF INDIA [17], [18]}

\begin{tabular}{|c|c|}
\hline Implementing Agency & Details \\
\hline PSPCL, at Tech-II & Total cost of project: Rs. 10.11 Crores. \\
\hline Sub division, SAS & MoP Share: Rs. 5.06 Crores. \\
\hline Nagar, Punjab & Project area has 2,737 number of consumers. \\
\hline & Annual consumption: 112.80 Million Units (MU). \\
\hline $\begin{array}{l}\text { UHBVN, at Panipat city sub divison, } \\
\text { Haryana }\end{array}$ & Total cost of project: Rs. 35.94 Crores. Project covers 11,000 consumers. \\
\hline HPSEB, at Kala & Total cost of project: Rs. 17.84 Crores. \\
\hline Amb industrial area, & MoP Share: Rs. 8.92 Crores. \\
\hline Himachal Pradesh & Number of consumers covered: 1,251 \\
\hline IIT Kanpur campus, Uttar Pradesh & Total cost of project: Rs. 12.5 Crores. \\
\hline & MoP Share: Rs. 6.25 Crores. \\
\hline & This project develops a smart city prototype and research and development \\
\hline & platform for small distribution system. \\
\hline
\end{tabular}

\section{TABLE VI: PILOT PROJECTS IN EASTERN REGION OF INDIA [17], [18]}

Implementing Agency

APDCL, at Guwahati

Distribution Region,

Assam
Details

Total cost of project: Rs. 29.94 Crores.

MoP Share: Rs. 14.97 Crores.

No. of consumers covered by pilot project:

15,000 . 
International Journal of Trend in Scientific Research and Development (IJTSRD) ISSN: 2456-6470

\begin{tabular}{|l|l|}
\hline & Annual energy: 90 MUs of input energy. \\
\hline $\begin{array}{l}\text { WBSEDCL, at Siliguri } \\
\text { Town, Darjeeling, }\end{array}$ West Bengal & $\begin{array}{l}\text { Total cost of project: Rs. 7.03 Crores. } \\
\text { MoP Share: Rs. 3.52 Crores. } \\
\text { Project covers 5,725 consumers. } \\
\text { Overall energy consumption: } 7.46 \text { MU/annum. }\end{array}$ \\
\hline $\begin{array}{l}\text { CSPDCL, at Siltara- DDU Nagar, } \\
\text { Chhattisgarh }\end{array}$ & $\begin{array}{l}\text { Total cost of project: Rs. 5.55 Crores. } \\
\text { MoP Share: Rs. 2.78 Crores. } \\
\text { No of consumers: 1897, dominated by domestic } \\
\text { consumers. }\end{array}$ \\
\hline TSECL, at Division no. 1, Agartala, Tripura & $\begin{array}{l}\text { Total cost of project: Rs. 24.08 Crores. } \\
\text { MoP Share: Rs. 12.04 Crores. } \\
\text { Projected area covers 42,676 consumers. }\end{array}$ \\
\hline
\end{tabular}

\section{TABLE VII: PILOT PROJECTS IN WESTERN REGION OF INDIA [17], [18]}

\begin{tabular}{|c|c|}
\hline Implementing Agency & Details \\
\hline $\begin{array}{l}\text { UGVCL, at Naroda of } \\
\text { Sabarmati Circle and DeesaII of Palanpur } \\
\text { circle, Gujarat }\end{array}$ & $\begin{array}{l}\text { Total cost of project: Rs. } 48.78 \text { Crores. } \\
\text { MoP Share: Rs. } 24.39 \text { Crores. } \\
\text { Project covers } 20,524 \text { consumers in Naroda and } 18,898 \\
\text { agriculture unmetered consumers in Deesa-II division. } \\
\text { Input energy is around } 1700 \mathrm{MU} \text {. }\end{array}$ \\
\hline $\begin{array}{l}\text { JVVNL, at Sanganer sub division, Jaipur } \\
\text { Rajasthan }\end{array}$ & $\begin{array}{l}\text { Total cost of project: Rs. } 33.38 \text { Crores. } \\
\text { MoP Share: Rs. } 16.69 \text { Crores. } \\
\text { No of consumers covered: } 34,752 \text {. } \\
\text { Input energy is } 148.12 \mathrm{MU} \text {. }\end{array}$ \\
\hline MSEDCL, at Baramati Town, Maharashtra & $\begin{array}{l}\text { Total cost of project: Rs. } 28.21 \text { Crores. } \\
\text { MoP Share: Rs. } 14.11 \text { Crores. } \\
\text { Project covering } 25,629 \text { consumers. } \\
\text { Input energy is } 261.6 \mathrm{MU} \text {. }\end{array}$ \\
\hline
\end{tabular}

TABLE VIII: PILOT PROJECTS IN SOUTHERN REGION OF INDIA [17], [18]

Implementing Agency

CESC, at VV Mohalla division, Mysore

TSSPDCL, at Jeedimetla Industrial

Area, Telangana

PED, at Division no. 1, Puducherry

KSEB, Kerala implemented at selected distribution area.

\section{Details}

Total cost of project: Rs. 32.59 Crores.

MoP share: Rs. 16.30 Crores.

Involved consumers: 21,824 .

Annual billed energy: 151.89 MU.

Total cost of project: Rs. 41.82 Crores.

MoP Share: Rs. 21.91 Crores.

Projected area covers 11,904 consumers.

Total cost of project: Rs. 46.11 Crores.

MoP Share: Rs. 23.06 Crores.

Project covers 87,031 consumers.

Input energy is $367 \mathrm{MU}$.

Total cost of project: Rs. 27.58 Crores.

MoP Share: Rs. 13.79 Crores.

25,078 Industrial consumers.

Input energy for total scheme is 2,108 MU. 


\section{KEY ISSUES AND CHALLENGES IN SMART GRID DEPLOYMENT}

The key obstructions that impedes the organization of savvy lattice innovations in India are as per the following -

a) The primary test looked by the arrangement producers is substantial beginning arrangement cost and prerequisite of expansive correspondence organize. Absence of correspondence framework in numerous remote regions of India is a blocking factor.

b) For contamination control and dispersed age innovative advancement for coordination with sustainable power source assets is fundamental.

c) It is basic to incorporate the whole equipment framework to oversee vast measure of information safely and store it for future reference. The danger of digital assaults increments with increment in buyers.

d) Lack of data among buyers upsets the improvement. Utilities and approach producers will play an imperative part in this.

\section{CONCLUSIONS}

India is one of only a handful couple of nations on the planet to take activities for improvement of shrewd lattice. Appropriately in 2010, India Smart Grid Task Force and India Smart Grid Gathering were built up and Ministry of Power, Government of India started undertaking and plans for accomplishing errands/drivers of shrewd matrix in 2015. India has set an objective for introducing 50 million savvy meters by 2020 . Sustainable power source infiltration in India till December 2016 was around 16\% with $50.02 \mathrm{GW}$ of sustainable power source introduced limit. Based on necessities unique nations have diverse advantages through framework modernization furthermore, as needs be they have made approaches as talked about in this paper. Right now, in India fundamental point is giving continuous energy to all. Key difficulties related with the improvement ought to be remembered for broad arrangement. In the event that these ventures are actualized effectively, they will bolster the future objectives and give ideal answer for meeting the developing needs of vitality in the nation.

\section{REFERENCES}

1. Knapp, E. D., and Samani, R. 2013. Applied Cyber Security and the Smart Grid: Implementing Security Controls into the Modern Power Infrastructure. New York: Elsevier Inc.

2. McLaughlin, S. 2009. "Energy Theft in the Advanced Metering Infrastructure." IEEE Journal on Selected Issues in Communications 6027 (15): 176-87.

3. Molazem, F. 2012. "Security and Privacy of Smart Meters: A Survey." In Overview of Computer Security, British Columbia: University of British Columbia.

4. Country statistical profile, OECD Factbook statistics: India 2013 [Online]. Available: (http://dx.doi.org/10.1787/csp-ind-table- 2013-1en).

5. Government of India, Central Electricity Authority [Online]. Available:(http://www.cea.nic.in/reports/monthly/ executive_rep/mar13/mar13.pdf).

6. Government of India, Central Electricity Authority

[Online]. Available:(http://www.cea.nic.in/reports/monthly/ gm_div_rep/power_supply_position_rep/energy/E nergy_2013_03.pdf).

7. Government of India, Central Electricity Authority [Online]. Available:(http://www.cea.nic.in/reports/monthly/ gm_div_rep/power_supply_position_rep/peak/Pea k_2013_03.pdf).

8. Jawaharlal Nehru National Solar Mission, Phase II - Policy Document: Ministry of New and Renewable Energy, December 2012.

9. Report on "National Electric Mobility Mission Plan 2020"."Federal Energy Regulatory Commission Assessment of Demand Response \& Advanced Metering" (PDF). United States Federal Energy Regulatory Commission.

10. Ye, Y., and Qian, Y. 2012. "A Survey on Smart Grid Communication Infrastructures: Motivations, Requirements and Challenges." IEEE Communications Surveys and Tutorials 15 (1): 520 .

11. Knapp, E. D. 2011. Industrial Network Security: Securing Critical Infrastructure Networks for 
Smart Grid, SCADA, and Other Industrial Control Systems. New York: Elsevier Inc.

12. Ye, Y., and Qian, Y. 2012. "A Survey on Smart Grid: A Communication Infrastructures: Motivations, Requirements and Challenges." IEEE Communications Surveys and Tutorials 15 (1): 5-20.

13. Richter, A. 2012. "Transitioning from the Traditional to the Smart Grid: Lessons Learned from Closed Loop Supply Chains." In Proceedings of the 2012 International Conference on Smart Grid Technology, Economics and Policies, 1-7.

14. Pepermans, G. 2005. "Distributed Generation: Definition, Benefits and Issues." Energy Policy 33 (6): 787-98. 